\title{
Regional Origins of Employment Volatility: Evidence from German States
}

\author{
Claudia M. Buch \\ MARTIN SCHLOTTER
}

CESIFO WORKING PAPER NO. 2296

CATEGORY 4: LABOUR MARKETS

MAY 2008
An electronic version of the paper may be downloaded
- from the SSRN website:
- from the RePEc website:
- from the CESifo website:
www.SSRN.com
www.RePEc.org
www.CESifo-group.org/wp




\title{
Regional Origins of Employment Volatility: Evidence from German States
}

\begin{abstract}
Openness for trade can have positive welfare effects in terms of higher growth. But increased openness may also increase uncertainty through a higher volatility of employment. We use regional data from Germany to test whether openness for trade has an impact on volatility. We find a downward trend in the unconditional volatility of employment, which has been interrupted by the re-unification period. Patterns are similar to those for output volatility. The conditional volatility of employment, measuring idiosyncratic developments across states, in contrast, has remained fairly unchanged. In contrast to evidence for the US, we do not find evidence for a significant link between employment volatility and trade openness.
\end{abstract}

JEL Code: F41, E32, R23.

Keywords: employment volatility, trade openness, regional labour markets.

\author{
Claudia M. Buch \\ University of Tübingen \\ Economics Department \\ Mohlstrasse 36 \\ 72074 Tübingen \\ Germany \\ claudia.buch@uni-tuebingen.de
}

\author{
Martin Schlotter \\ Ifo Institute for Economic Research \\ at the University of Munich \\ Poschingerstrasse 5 \\ 81679 Munich \\ Germany \\ schlotter@ifo.de
}

April 2008

The authors would like to thank Jörg Breitung, Geraldo Cerqueiro, Steven Ongena, Dirk Ulbricht, Oliver Falck and seminar participants at Humboldt University (Berlin) and the ifoInstitute (Munich) for most helpful discussions. All errors and inaccuracies are solely in our own responsibility. 


\section{Motivation}

There is wide-spread concern in the population and among policy makers that increased international integration could increase the uncertainty faced by workers. Globalization could then be a double-edged sword. On the one hand, international integration is associated with higher economic growth. On the other hand, employment conditions may become more unstable, thus aggravating the fear of workers to become unemployed.

Earlier empirical studies testing the link between trade openness and employment volatility use cross-country panel data. These studies have the disadvantage that countries may have different labor market institutions and different degrees of financial openness. This may affect the link between trade openness and employment volatility.

In this paper, we use regional data from Germany to show trends in employment volatility over the past 40 years, and we test whether openness for trade has had an impact on volatility. Using regional data from a single country has the advantage that differences in institutions do not affect our results. Also, macroeconomic developments are similar across the regions. Our study is motivated by a partial-equilibrium model of regional labor markets, which we adopt from Blanchard and Katz (1992). The model stresses the importance of structural and cyclical factors such as labor market regulations and the industrial structure determining the volatility of employment at the regional level. Previous empirical literature has studied the link between openness and volatility from three different angles.

A first related set of studies has studied the long-run evolution of output volatility. The impact of the globalization process on the volatility of employment has been studied less 
frequently. This literature finds evidence for a smaller volatility of output - the so-called 'Great Moderation' - across developed countries as a result of a combination of smaller shocks, better inventory management, and better monetary policy (Blanchard and Simon 2001, Stock and Watson 2004). Aßmann et al. (2006) and Buch et al. (2004) provide corresponding evidence for Germany. Generally, studies at the country- or sector-level find that greater trade openness tends to have increased output volatility (Easterly et al. 2000, Braun and Larrain 2004, Kose et al. 2003).

A second set of studies uses regional data to avoid the problem that outcomes across countries might be driven by differences in institutions. Carlino, DeFina, and Sill (2003) use a state-level panel dataset for the US to explain the post-war pattern of employment volatility. They find a decline in employment volatility, which is the result of two counterbalancing forces. On the one hand, the volatility of macroeconomic aggregates has declined and this has dampened the volatility of employment. On the other hand, greater openness to foreign trade has tended to increase employment volatility. Morgan, Rime, and Strahan (2003) find that the lifting of barriers to cross-state-border entry in US banking lowered fluctuations in employment growth. These results suggest that trade integration may increase while financial integration might dampen employment volatility. Owyang, Piger, and Wall (2006) look for evidence for the ‘Great Moderation’ at the level of US states. They find significant heterogeneity in the timing and the magnitude of reductions in state-level employment volatility. Hammond and Thompson (2004) study the impact of industrial and demographic characteristics for regional employment volatility in the US. Both papers do not address the impact of openness on volatility. 
A third related strand of literature studies the link between openness and employment volatility by investigating the elasticity of labor demand. For a given macroeconomic shock, employment should fluctuate more if the labor demand elasticity of firms increases (Rodrik 1997). Fabbri, Haskel, and Slaughter (2003) analyze industry-level data for UK and US firms. They find that labor demand has become more elastic over time. Barba Navaretti et al. (2003) use firm-level data for Europe to show that multinationals adjust employment faster than national firms. However, the elasticity of labor demand is similar for multinationals and national firms. For Germany, results in Buch and Lipponer (2007) support this finding.

In this paper, we study the link between employment volatility and openness for a statelevel dataset for Germany. For the eleven West German states, we have data for the years 1970-2005; data for the five East German states start in 1991. Our work differs from earlier studies along three dimensions. First, as in earlier studies for the US, the use of state-level data has the advantage that differences in institutions do not matter. Second, in contrast to firm-level studies on labor demand elasticities, we provide evidence on the aggregated implications of trade openness for employment volatility. Hence, we investigate not only whether employment has become more or less stable for particular firms but whether entire regions are affected. Third, we complement earlier evidence for the US using data for Germany. From a methodological point of view, we follow the literature in estimating the determinants of employment volatility in a panel framework. Additionally, we go beyond earlier literature and estimate a heteroscedastic regression model, which allows a simultaneous modeling of employment growth and the variance of employment growth. 
In Part Two, we give a summary of the theoretical determinants of employment volatility, and we explain how we measure these. In Part Three, we discuss the measurement of employment volatility, and we provide stylized facts. In Part Four, we present our

empirical model, regression results, and robustness tests. Part Five concludes. Overall, we do not find evidence for a link between employment volatility and trade openness at the state-level. This result is robust against using conditional and unconditional measures of employment volatility. While we find a positive link between openness and volatility in selected specifications, this result is driven by individual states hosting large international harbors. For the average German state, greater openness has not been associated with greater instability of employment. Moreover, our results suggest that a higher share of the services sector and more rigid labor markets lower the volatility of employment.

\section{Determinants of Employment Volatility: Theory and Measurement}

This section uses a model of regional labor markets to derive theoretical determinants of regional employment volatility. We then describe how we measure these determinants using German state-level data.

\subsection{Theoretical Background}

Regional characteristics, labor demand and supply shocks, and the response to these shocks affect the volatility of employment at the regional level. This can be shown using a model of regional labor markets as suggested by Blanchard and Katz (1992) and applied to an analysis of employment volatility by Hammond and Thompson (2004). In their model, regional labor demand is a negative function of wages: 


$$
w_{i t}=-d\left(n_{i t}^{*}-u_{i t}\right)+z_{i t}
$$

where $w_{i t}$ denotes wages in region $i$ relative to the national wage level, $u_{i t}$ is the unemployment rate, and $n_{i t}^{*}$ denotes the regional labor force. Unemployment falls in wages: $c w_{i t}=-u_{i t}$. Labor demand changes over time as new firms enter a region. Hence, $z_{i t}$ reflects the response of firms to the structural demand-side patterns of the regional economy $\left(x_{i}^{D}\right)$ as well as shocks to labor demand $\left(\varepsilon_{i, t+1}^{D}\right)$ :

$$
z_{i, t+1}-z_{i, t}=-a w_{i t}+x_{i}^{D}+\varepsilon_{i, t+1}^{D}
$$

In an open economy, shocks to labor demand can further be decomposed into a weighted average of domestic $(H)$ and foreign shocks $(F): \varepsilon_{i, t+1}^{D}=\omega \varepsilon_{i, t+1}^{D, H}+(1-\omega) \varepsilon_{i, t+1}^{D, F}$ where $\omega$ is the weight of the home market in total sales. Foreign shocks are business cycle developments abroad which are, for instance, propagated through foreign trade links. The wage elasticity of labor demand ( $a$ ) depends on factors such as the industrial structure of the regional economy, the ease with which capital can be substituted for labor, or labor market regulations. We take this wage elasticity as a parameter, but it could also vary with the degree of trade openness.

Growth in regional labor supply is given by:

$$
n_{i, t+1}^{*}-n_{i, t}^{*}=b w_{i t}-g u_{i t}+x_{i}^{S}+\varepsilon_{i, t+1}^{S}
$$

where structural factors are given by $x_{i}^{S}$, and shocks to labor supply are denoted by $\varepsilon_{i, t+1}^{S}$. In an open economy, we can again decompose these into a domestic and a foreign component: $\varepsilon_{i, t+1}^{S}=\lambda \varepsilon_{i, t+1}^{S, H}+(1-\lambda) \varepsilon_{i, t+1}^{S, F}$ where $\lambda$ denotes the weight of the domestic labor 
supply shock. International migration would be one channel through which foreign factors have an impact on the domestic labor market.

Solving the model, equilibrium mean employment growth can be written as the sum of an autoregressive process, of the long-run structural parameters of the economy, and of demand and supply shocks:

$$
\begin{aligned}
\Delta n_{i, t+2}^{*}= & \frac{1}{1+c d}\left[\Delta n_{i t+1}^{*}(1+c d+a-d b-c d g)-(1+c d+a) \varepsilon_{i, t+1}^{S}\right. \\
& \left.+(b+c g)\left(x_{i}^{D}+\varepsilon_{i, t+1}^{D}\right)+a x_{i}^{S}\right]+\varepsilon_{i, t+2}^{S}
\end{aligned}
$$

or

$$
\Delta n_{i, t+2}^{*}-\alpha_{1} \Delta n_{i t+1}^{*}=\alpha_{2} \varepsilon_{i, t+1}^{S}+\alpha_{3}\left(x_{i}^{D}+\varepsilon_{i, t+1}^{D}\right)+\alpha_{4} x_{i}^{S}
$$

where the coefficients $\alpha_{1}-\alpha_{4}$ summarize the model's structural parameters affecting labor demand and supply: $\alpha_{1}=\frac{1+c d+a-d b-c d g}{1+c d}, \alpha_{2}=\frac{1+c d+a}{1+c d}+1, \alpha_{3}=\frac{b+c g}{1+c d}$, and $\alpha_{4}=\frac{a}{1+c d}$. Equation (4') can also be used to compute the variance of employment as a function of the underlying shocks:

$$
\begin{aligned}
\sigma^{2}\left(\Delta n_{i, t+2}^{*}\right) & =E\left[\Delta n_{t+1}-E\left(\Delta n_{t+1}\right)\right]^{2} \\
& =\alpha_{2} \sigma^{2}\left(\varepsilon_{i, t+1}^{S}\right)+\alpha_{3} \sigma^{2}\left(\varepsilon_{i, t+1}^{D}\right)+\alpha_{2} \alpha_{3} \sigma\left(\varepsilon_{i, t+2}^{D}\right) \sigma\left(\varepsilon_{i, t+2}^{S}\right)
\end{aligned}
$$

where $\sigma^{2}$ denotes the variance of the respective variable. Hence, the volatility of regional employment depends on the volatility of demand and supply shocks which, in turn, depend on domestic and foreign demand and supply conditions, and on the response of the regional economy to these shocks. Equation (5) - the variance equation - will be the basis for our empirical estimates below. 
In our empirical model, we capture the exposure to foreign shocks through a region's degree of trade openness. Equation (4') also shows that the parameters of the model such as the wage elasticity of labor demand ( $a$ ), the wage elasticity of labor supply $(b)$, the response of unemployment to wages $(c)$, the response of wages to employment $(d)$, and the response of migration to unemployment $(g$ ) affect the volatility of employment. Since our main testing equation will be based on a reduced form model derived from (5), we will not estimate these parameters. However, we will control for the structural characteristics of the regional economies that affect these parameters. In the following, we describe the measurement of openness and regional control variables in more detail.

\subsection{Trade Openness}

In the context of the above model, trading more with the rest of the world can have a double-edged impact on employment volatility. On the one hand, countries or regions become exposed to foreign shocks, and volatility might increase. This effect might be aggravated by an increase in the wage elasticities of firms (b) (Rodrik 1997). On the other

hand, $\sigma^{2}\left(\varepsilon_{i, t+1}^{S}\right)$ and $\sigma^{2}\left(\varepsilon_{i, t+1}^{D}\right)$ depend on the covariance of domestic and foreign shocks.

If domestic and foreign shocks are imperfectly correlated, this might lower the volatility of employment.

To test the link between employment volatility and trade openness empirically, we compute the ratio of the sum of imports and exports and GDP. Since we have this information at the state-level, we can approximate the integration of the states into the world economy. By splitting openness into import and export openness, we also investigate the channels through which trade and employment volatility are linked. 


\subsection{Labor Market Regulations}

Labor market regulations are likely to affect the elasticity of labor demand. Since we use regional data for Germany, we cannot test the effects of changes in labor market regulations that affect all states alike. However, there is evidence for a variation in the implementation of labor market regulations at the state-level due to a nomination bias of the judges to higher-level labor courts. According to evidence in Berger and Neugart (2007), the composition of higher-level labor courts affects the strategic behavior of workers and employers in their decision on taking a case to lower-level labor courts. The authors show that this has an impact on the unemployment rate in the respective state.

In this paper we proxy the degree of labor market rigidity across states using the share of long-term unemployment. A positive correlation between employment protection and long-term unemployment was shown by Jahn (2002). Several cross-country studies support this finding using panel data for OECD countries, using rankings of dismissal protection between countries as the dependent variable. For example, Nickell (1999) and Scarpetta (1996) show a positive effect of employment protection regulations on longterm unemployment. Nevertheless, this proxy is incomplete for two reasons. First, empirical research generally finds it difficult to establish a strong link between employment protection laws and the overall rate of unemployment (Freeman 2007). Second, long-term employment depends on both, structural features of the labor market as well as on demographic characteristics of the working age population. The time invariant component of demographic factors will be picked up by state fixed effects. Moreover, from a theoretical point of view, the impact of employment protection legislation and union power on the volatility of employment is not clear-cut. On the one 
hand, the degree of unionization could have an impact on employment volatility if unions try to preserve employment and to reduce the flexibility of labor markets. Thus, we expect a negative correlation between the degree of unionization and the volatility of employment. Longhi et al. (2005), for instance, show empirically that the variation of unemployment decreases in the degree of centralization of the system of wage bargaining. On the other hand, employment protection legislation increases the fixed costs of laying off workers. Hence, large adjustments of the labor force may become more likely, and employment volatility might increase.

To measure the importance of unions, we use the share of employees organized in German unions for every year from 1970-2005. Note that we can use this variable only if we do not include time fixed effects. Hence, this variable may also measure other omitted factors that follow a trend development over time. To account for the fact that the degree of unionization differs across sectors, we additionally include a proxy for the share of services in total output. The degree of unionization in the services sector is traditionally lower than in the manufacturing sector.

\subsection{Industrial Diversification}

The degree of industrial diversification captures the responsiveness of labor demand to shocks. Understanding the link between the regional industrial structure and economic stability has been an important research question in regional economics (Conroy 1975). This literature shows that specialization can be a double-edged sword. On the one hand, industry specialization along comparative advantages in certain industrial sectors might 
increase growth. On the other hand, it could increase volatility by increasing the exposure to industry-specific shocks.

Empirical research provides mixed evidence on the volatility effects of specialization. Maliza and Ke (1993) and Simon and Nardelli (1992) find a stabilizing effect of industry diversification across US metropolitan areas. A study of Izraeli and Murphy (2003) confirms this result for US states. Attaran (1986) and Jackson (1984), in contrast, do not find any link between the industrial structure of a region and economic stability. Hammond and Thompson (2004) find that the impact of industrial structure weakens as demographic factors are included in the model.

Here, we follow earlier literature and use a Herfindahl Index as a measure of the degree of industrial diversification. We take the number of workers in 15 different sectors in every German state and create an annual Herfindahl Index for the years 1991-2004. We can use this variable for the final decade of our sample only.

\subsection{Macroeconomic Developments}

In standard open economy macro models, the link between openness and volatility depends on the nature of the underlying macroeconomic shock (see, e.g., Senay 1998). Since we are considering regions within one country, monetary developments are the same for all regions. The same holds true for international macroeconomic developments such as oil price shocks. These variables are captured through time fixed effects.

However, fiscal policy shocks may differ across regions. To account for the volatility of fiscal policy, we use data from the German Federal Statistic Office which gives aggregated government revenues and expenditures at the state level. We have this 
information since 1985 for the West German states and since 1991 for the East German states.

\subsection{Population Characteristics}

Population characteristics that influence mobility of workers can be an important driver of regional differences in employment volatility. For example, workers who are attached to a specific region or who have more non-labour income will be less inclined to migrate due to a shock that influences labor markets (Hammond and Thompson 2004).

In general, the costs of migration between states could be a key factor determining employment volatility. Schöb and Wildasin (2007) show that greater integration between regions, measured in lower migration costs, leads to more flexible labour markets and increase fluctuations.

The most prominent result of the literature linking migration and employment volatility is the importance of population`s skill structure. Empirical literature on migration shows that the educational attainment of individuals is positively correlated with their propensity to migrate and therefore has a positive impact on employment volatility. High-skilled individuals can be expected to have lower migration costs than low-skilled workers. We have account for this by including the share of high-skilled workers within each German state in our regressions. Since the skill structure has been insignificant and since our main results do not change including this variable, we do not report these results though. 


\section{Employment Volatility: Measurements and Stylized Facts}

\subsection{Measuring Employment Volatility}

To measure employment volatility, we use data on the annual average number of employees at the state level for the years 1970-2005. We cannot divide employees into full time and part-time workers since data are not available for a sufficiently long time period. Hence, every employee is weighted equally, independent of his or her numbers of hours worked.

We begin by calculating the growth rate of employment. As we are interested in the cyclical evolution of employment, we apply the Hodrick-Prescott-Filter to isolate the cyclical from the trend growth in employment. The relative importance of the trend and the cyclical component depends on the value of a smoothing parameter $\lambda$. We follow Ravn and Uhlig (2003) who suggest a value of 6.25 for annual data.

Using the growth of the cyclical component of employment, we compute the squared growth rates $\Delta n_{i t}^{2}$ as a measure of unconditional employment volatility. Previous literature uses the rolling standard deviation over a five-years-window (see, e.g., Braun and Larrain 2004 or Carlino et al. 2003). The volatility $\sigma\left(\Delta n_{i t}\right)$ of the cyclical component of employment growth $\Delta n_{i t}$ in state $i$ at time $t$ is then given by

$$
\sigma\left(\Delta n_{i t}\right)=\sqrt{\frac{\sum_{k=0}^{4}\left(\Delta n_{i, t+k}-\Delta \bar{n}_{t+k}\right)^{2}}{5}}
$$

However, this measure of volatility has the disadvantages that the 5-year window is chosen somewhat arbitrarily and that the measure of volatility is autocorrelated by 
definition. Hence, we have checked the robustness of our results using the 5-year standard deviation only for successive five year periods to obtain a quasi panel.

In addition to the 'unconditional' volatility, we also compute the 'conditional' idiosyncratic volatility of employment growth in state $i$ using the residuals $\left(\varepsilon_{i t}\right)$ of a regression of employment growth on a set of time fixed effects (to capture country-wide business cycle effects) and lagged employment growth in state $i$ :

$\Delta n_{i t}=\alpha_{0}+\alpha_{1} \sum_{k=1}^{5} \Delta n_{i t+k}+\alpha_{2} T_{t}+\varepsilon_{i t}$ where $T_{t}$ is a vector of time fixed effects. (See Blanchard and Simon (2001), Carlino et al. (2003), or Hammond and Thompson (2004) for similar approaches.) The correlation between conditional and unconditional employment volatility is 0.26 . Hence, employment persistence and aggregated developments account for about two-thirds of the variation in employment growth across states. Again, we take the squared residual $\varepsilon_{i t}{ }^{2}$ as a measure for the employment volatility in state $i$ in period $t$.

\subsection{Stylized Facts}

Figure 1 plots the evolution of employment volatility at the state level. Using the unconditional volatility, we find a reduction of employment volatility, which was interrupted by the reunification period (see also Buch et al. (2004) and Aßmann et al. (2006), in all German states except Berlin. The conditional volatility does not show this clear pattern. There is a considerable reduction of volatility in some states (for example Bayern and Saarland) whereas employment in other states became more unstable over time (for example Niedersachsen and Hamburg). Unreported time series regressions of employment volatility for each West German state on its own five lags, a reunification 
dummy, and a time trend support this. The time trend is negative and significant for four out of eleven states using the unconditional volatility. It is positive and significant for four states when using the conditional volatility. Hence, while the unconditional volatility mirrors the decline in aggregate volatility, idiosyncratic, state-level developments differ.

Differences in volatility could be driven by differences in trade openness. Figure 2 plots the degree of trade openness by state. While all states have become more integrated into the world economy over the sample period, the degree of this increase differs across states. Moreover, as hosts of seaports, the city states Bremen and Hamburg have aboveaverage export and import shares. We will account for the possibility that these outliers drive our results by including interaction terms for Hamburg and Bremen and openness.

We have three more variables which vary over time and states. The first is the (unconditional) volatility of output growth, which shows similar patterns as the volatility of employment. The descriptive statistics in Table 1 also show that the mean volatility of output growth is higher than the mean volatility of employment growth. The second variable that varies across states and time is the importance of the service industry in terms of the share of employees in the service sector. This share has increased for all states. While, at the beginning of the sample, only slightly above $40 \%$ of all employees were occupied in services industries, this share had increased to about $70 \%$ towards the end of the sample. The increase in the importance of services has been particularly important in the East German states during the last fifteen years, reflecting the bias of the system of central planning towards manufacturing industries. Finally, across all German states, unemployment rates have been on a trend rise throughout the sample period. 


\section{Determinants of Employment Volatility}

To analyze the determinants of employment volatility for a panel of 16 German states for the past four decades (1972-2005), we employ two different methodologies. First, we look at the determinants of conditional and unconditional employment volatility. Second, we use a heteroscedastic regression model to simultaneously estimate the mean and the variance equation derived above (see Section 2.1).

\subsection{Regression Model: Determinants of Employment Volatility}

Our first empirical model links the standard deviation of employment growth to openness and aggregated shocks:

$$
\Delta n_{i t}^{2}=\alpha_{1 i}+\beta_{1} X_{i t}+\beta_{2} X_{t}+\beta_{4} \Delta y_{i t}^{2}+\beta_{5} \text { Open }_{i t}+u_{i t}
$$

where $\Delta n_{i t}^{2}=$ squared cyclical component of employment growth in state $i$ at time $t$, $\alpha_{1 i}=$ state-fixed effects, $X_{i t}=$ time-varying explanatory variables at the state-level, $X_{t}=$ time-varying explanatory variables at the country-level, $\Delta y_{i t}^{2}=$ squared cyclical component of output growth, and Open $_{i t}=$ trade openness of states. As an alternative to including the time-varying explanatory variables, we include a full set of time fixed effects $\left(T_{t}\right)$. These account for business cycle effects such as changes in monetary policy and other aggregate shocks affecting all states alike. $u_{i t}$ is the error term.

We follow Arellano (1987) and compute robust standard errors which allow for both heteroscedasticity and autocorrelation of arbitrary form. In addition, we use a quasi-panel 
with non-overlapping observations as a robustness test. (See Braun and Larrain (2004) for an application to industry-panel data.)

\subsection{Regression Results: Employment Volatility}

Regression results for the determinants of employment volatility at the regional level in Germany are reported in Table 2. We estimate the model separately for the full sample of 16 states (Table 2a) and for the sample of 10 West German states (excluding Berlin) (Table 2b). This accounts for the fact that the East German states might exhibit special characteristics due to the post-unification catching up process. Since most results are similar for the two specifications, we will report only the main differences below. Generally, a full set of time fixed effects is included. The exception is the specification in Column 7, which includes the long-term unemployment rate and the degree of unionization, which do not vary across the German states.

Our baseline specification includes the volatility of output growth, trade openness, a reunification dummy, and time fixed effects as explanatory variables (column 1). We modify this specification splitting trade into imports and exports (columns 2 and 3), adding the volatility of government spending and revenues (column 4), adding a proxy for the degree of industry diversification (column 5), the state-level unemployment rate and the share of the services sector (column 6). In columns 8-10, we re-estimate the model for the conditional employment volatility and the three proxies for trade openness. In terms of the explanatory power, our model performs quite well with an adjusted $R^{2}$ of 0.29-0.74, depending on the specification chosen. 
Our first finding is that we have a positive and significant coefficient of output volatility. We should be careful when interpreting this as a causal effect of output volatility on unconditional employment volatility because of the endogeneity problems which arise by using output volatility as an explaining variable for employment volatility. In fact, reestimating the model and instrumenting output growth volatility by its own lags yields an insignificant coefficient. For the West German sub-sample, the coefficient on output volatility is insignificant if we use the conditional volatility of employment and output growth instead, suggesting that the unconditional volatility of output growth picks up the persistence and autocorrelation of employment volatility.

Trade openness, the main variable of interest in this paper, has no significant impact on the volatility of employment in the full sample. Considering import and export openness separately shows a weakly significant impact of export openness in the specification using the conditional employment volatility as the dependent variable. If anything, results for the West German states show a somewhat stronger positive impact of trade openness on employment volatility. However, as will be discussed in more detail below, this result is driven by one state - Bremen -, which hosts a large international harbor.

Fiscal volatility at the state level could affect the volatility of employment as well. Our data start in 1985 for West Germany and 1992 for East Germany. We find a positive link between the volatility of government spending and employment volatility for the full sample for the West German states. However, this effect is statistically significant only at the $10 \%-l e v e l$.

Variables capturing the industrial structure and the regulation of the labor market have a mixed impact. The degree of industry diversification, measured through the Herfindahl 
index, is insignificant. Note, however, that we have this information only for later sample periods. A higher share of employment in the service sector is associated with lower employment volatility (for the West German state, this variable is insignificant). This finding would be consistent with the hypothesis that the demand for services is more stable than the demand for manufacturing output. It could also reflect a lower degree of exposure of the services sector to foreign competition.

The state-level unemployment rate as a measure for the degree of labor market rigidities is insignificant. For two other measures for the rigidity of labor market regulations, the long-term unemployment rate and the degree of unionization, we have information only at the aggregated level. A higher long-term unemployment rate and a higher degree of unionization are associated with a lower volatility of employment in the West German sub-sample. This could be an indication that, the more regulated the labor market, the lower is the volatility of employment. Since the degree of unionization varies only over time and not across states - and thus drops out when time fixed effects are included - it might capture other, unobserved macroeconomic developments though and should thus be interpreted with caution.

\subsection{Robustness Tests}

In addition to the various modifications of the baseline specifications, we have also run our model as a quasi-panel on non-overlapping windows of employment volatility. Results are reported in Table 3 and are similar to those reported above. The main exceptions are that we now find a negative link between import openness and unconditional employment volatility, that the variables capturing structural characteristics 
and labor market rigidities are now insignificant, and that higher volatility of government spending and revenues now increases employment volatility.

In a next step, we change the specification of employment volatility in our baseline regression. As in many previous papers in this literature, we use the standard deviation of employment growth as the dependent variable. In these specifications, the dependent variable is the volatility of employment growth for the five-year interval starting in period $t$. All other variables are measured in $t$. Hence, we test whether the explanatory variables have a statistically significant impact on subsequent employment volatility. In unreported regressions, we find qualitatively very similar results to those reported above.

One potential concern could be that our results are driven by individual states. As shown in Figure 2, trade openness increased in almost all German states. But the trade dynamics have been particularly pronounced in the city states Hamburg and Bremen, which host international sea harbors. In a robustness check, we thus estimate our baseline regressions without Hamburg and Bremen to check whether our results are driven by these two states. Results are reported in Table 4. They show that the results concerning the positive impact of openness on volatility are indeed driven by a single state - Bremen. We can corroborate this result if we introduce a new variable interacting a dummy for Bremen with our openness measures and estimate our baseline regressions for the whole sample (Columns 7 and 10 of Table 4). All openness measures become insignificant. We find a significant positive effect of our interaction term meaning that in this case, the pure variation of trade openness in Bremen almost drives the whole positive effect of trade openness on employment volatility. 


\subsection{Heteroscedastic Regression Model}

As an alternative empirical model, we estimate a regression model with multiplicative heteroskedasticity as proposed by Harvey (1976). The advantage of this model is that we can simultaneously specify a 'mean’ equation - explaining the growth of employment as well as a 'variance' equation - explaining the residual variance. Hence, we can empirically model employment growth in close correspondence to our theoretical model above.

The heteroscedastic regression model has, to the best of our knowledge, not been applied to an analysis of macroeconomic volatility so far. Earlier applications use the model to model heteroskedasticity in the residuals, but most of these papers do not focus on the estimation of the variance equation. Two exceptions are a recent paper by Cerqueiro et al. (2007), who study the loan pricing decisions of banks. Ang and Peterson (1985) estimate a capital asset pricing model and study both, the determinants of rates of returns and of the variance of returns.

According to the heteroscedastic regression model, the mean equation gives the level of employment at a function of a set of explanatory variables $X: \ln \Delta n_{i t}=X^{\prime}{ }_{i t} \beta+\varepsilon_{i t}$ where $\varepsilon_{i t}$ is the residual with $E\left[\varepsilon_{i t} \mid X_{i t}\right]=0$ and $\operatorname{VAR}\left[\varepsilon_{i t} \mid X_{i t}\right]=\sigma_{i t}^{2}=\exp \left\{Z^{\prime}{ }_{i j} \gamma\right\}$. The variance equation is given by $\ln \sigma_{i t}^{2}=Z_{i t}^{\prime} \gamma$. The coefficients $\beta$ and $\gamma$ can be obtained by maximizing a log-likelihood function. One advantage of this methodology is that the parameters of the mean and of the variance equation are uncorrelated. 
By containing both a mean and a variance equation, the heteroskedastic regression model already filters the cyclical component out of the data. Hence, we report results using unfiltered data. Results using filtered data are very similar and are available upon request. Our modeling strategy is to include as many variables as possible in the mean equation to predict employment as good as possible and to leave only the unexplained component of employment growth for the variance equation. In particular, our mean equation includes time dummies to account for aggregate fluctuations as well as state fixed effects to account for unobserved heterogeneity across states. In the variance equation, we likewise include a full set of time and state fixed effects. We again estimate the model separately for the full sample and for the West German states. ${ }^{1}$ While, in principle, we use similar specifications as above, we restrict the robustness tests with regard to structural variables to the unemployment rate and the share of the services sector in each state, and we add the growth rate of nominal wages as an additional regressor. Note that, while real wages would be the preferred measure of factor costs, we lack information on regional price indices. This is addressed by including time and state-fixed effects.

Results of the mean equation show, not surprisingly, that higher output growth is associated with higher employment growth whereas higher wage growth tends to have a dampening impact on employment growth. Interestingly, trade openness does not have a significant impact on employment growth in the regressions using filtered data, and the impact is even negative in the specifications using unfiltered data for West Germany. In these specifications, higher unemployment is associated with lower employment growth.

$1 \quad$ Since the model including all fixed effects did not converge for all specifications for West Germany, regressions for this sub-sample are estimated without regional fixed effects. 
This would be consistent with a negative impact of labor market rigidities on employment growth.

Turning next to the results of the variance equation, there is some evidence for a positive and significant impact of wage and output growth on the variance of employment growth. Higher growth would thus be associated with a higher volatility of growth. This would be at odds with the findings by Ramey and Ramey (1995), who find a negative correlation between growth and volatility across countries. Imbs (2007), in contrast, shows that the correlation between growth and volatility depends on the level of aggregation of the data. He finds a positive correlation between growth and volatility at the industry level. One explanation is that growth rates are imperfectly correlated across sectors. Our state-level data suggest a similar positive relationship.

In some specifications, there is evidence for a positive impact of trade openness on the variance of employment growth. This effect shows up in the full as well as in the West German sample. Moreover, the effect is driven by the degree of import openness.

Essentially, the finding that higher export openness is associated with a higher variance of employment growth corresponds to the findings using the panel and quasi-panel regressions above. Regressions using the residual volatility of employment growth as the dependent variables also showed a positive impact of trade openness on volatility, and this effect was driven by the degree of export openness. The dependent variable in the heteroscedastic regression model is similar to the dependent variable in these models, as it also captures the residual variance of employment growth. 


\section{Conclusions}

This paper has used German regional data to test how employment volatility has evolved over time and which factors account for these changes. We find that employment volatility has declined through the past decades, thus mirroring changes in aggregated output volatility. This process has been interrupted only by the reunification period in the early 1990s. Once we isolate idiosyncratic developments at the state level from macroeconomic trends, we find some weak evidence for an increase in employment volatility.

Overall, a higher share of employment in the services sector, a higher share of long-term unemployment, and a higher degree of unionization are associated with lower volatility of employment. Most of these results are driven by the West German states. This is consistent with the hypothesis that production in services is less cyclical and that labor market rigidities lower employment volatility. Also, higher volatility of government spending is correlated with higher volatility of employment growth.

The main interest of this paper has been the link between trade openness and the volatility of employment. In contrast to findings for the US, we do not find evidence for a positive link between employment volatility and trade openness. There is evidence for a positive link in selected specifications but these results are driven by states hosting international harbors and thus having an above-average exposure to foreign trade. For the average German state, greater trade openness has not been associated with a greater volatility of employment. 


\section{References}

Ang, J.S., and D.R. Peterson (1985). Return, Risk, and Yield: Evidence from Ex Ante Data. Journal of Finance 40(2): 537-548.

Arellano, M. (1987). Computing Robust Standard Errors for Within-groups Estimators. Oxford Bulleting of Economics and Statistics 49(4): 431-43.

Aßmann, C., J. Hogrefe, and R. Liesenfeld (2006). The Decline in German Output Volatility: A Bayesian Analysis. Christian-Albrechts-Universität Kiel. Working Paper 2006-02. Kiel.

Attaran, M. (1986). Industrial diversity and economic performance in U.S. areas. The Annals of Regional Science 20(2): 44-54.

Barba Navaretti, G., D. Checchi, and A Turrini (2003). Adjusting Labor Demand: Multinational versus national firms. Journal of the European Economic Association 1(2-3): 708-719.

Berger, H., and M. Neugart (2007). Labor Courts, Nomination Bias, and Unemployment in Germany. CESifo Working Paper 1752. München.

Blanchard, O.J., and L.F. Katz (1992). Regional Evolutions. Brookings Papers on Economic Activity 1: 1-75.

Blanchard, O.J., and J. Simon (2001). The Long and Large Decline in U.S. Output Volatility. Brookings Papers on Economic Activity 1: 135-164.

Braun, M., and B. Larrain (2004). Finance and the Business Cycle: International, InterIndustry Evidence. Anderson School, University of California, and Harvard University. Mimeo.

Buch, C.M., J. Döpke, and C. Pierdzioch (2004). Business Cycle Volatility in Germany. German Economic Review 5(4): 451-479.

Buch, C.M., J. Döpke, and C. Pierdzioch (2005). Financial Openness and Business Cycle Volatility. Journal of International Money and Finance 24 (5): 744-765.

Buch, C.M., and A. Lipponer (2007). Volatile Multinationals? Evidence from the Labor Demand of German Firms. Deutsche Bundesbank. Discussion Paper 22. Frankfurt a.M. 
Carlino, G., R. DeFina, and K. Sill (2003). Postwar period changes in employment volatility: new evidence from state/industry panel data. Working Papers 03-18, Federal Reserve Bank of Philadelphia.

Cerqueiro, G., H. Degryse, and S. Ongena (2007). Rules versus Discretion in Loan Rate Setting. CentER Tilburg University. Mimeo.

Conroy, M. E. (1975). The concept and measurement of regional industrial diversification. Southern Economic Journal 41(3): 492-505.

Easterly, W., R. Islam, and J.E. Stiglitz (2000). Shaken and Stirred: Explaining Growth Volatility. The World Bank. Washington D.C., mimeo.

Fabbri, F., J.E. Haskel, and M.J. Slaughter (2003). Does Nationality Of Ownership Matter For Labor Demands? Journal of the European Economic Association 1(2 3): 698-707.

Freeman, Richard B. (2007). Labor Market Institutions Around the World. National Bureau of Economic Research NBER. Working Paper 13242. Cambridge MA.

Hammond, G.W., and E. Thompson (2004). Employment Risk in U.S. Metropolitan and Nonmetropolitan Regions: The Influence of Industrial Specialization and Population Characteristics. Journal of Regional Sciences 44(3): 517-542.

Harvey, A. (1976). Estimating Regression Models with Multiplicative Heteroskedasticity. Econometrica 44: 461-465.

Imbs, J. (2007). Growth and Volatility. Journal of Monetary Economics 54 (2007) 18481862.

Izraeli, O., and K. J. Murphy (2003). The effect of industrial diversity on state unemployment rate and per capita income. The Annals of Regional Science 37(1): $1-14$.

Jackson, R. (1984). An evaluation of alternative measures of regional industrial diversification, Regional Studies, 18(2), S. 103-112.

Jahn, E.J. (2002). Zur ökonomischen Theorie des Kündigungsschutzes. Volatilität der Arbeitsnachfrage und duale Arbeitsmärkte. Duncker und Humboldt, Berlin.

Kose, M.A., E.S. Prasad, and M.E. Terrones (2003). Financial Integration and Macroeconomic Volatility. International Monetary Fund. Working Paper 03/50. Washington DC.

Kose, M.A., E.S. Prasad, and M.E. Terrones (2004). How Do Trade and Financial Integration Affect the Relationship between Growth and Volatility? IZA Discussion Paper 2252. 
Longhi, S., P. Nijkamp, and I. Traistaru (2005). Is sectoral diversification a solution to unemployment? Evidence from EU regions. Kyklos 58(4): 591-610.

Malizia, E.E., and S. Ke (1993). The influence of economic diversity on unemployment and stability. Journal of Regional Science 33(2): 221-235.

Morgan, D.P., B. Rime, and P.E. Strahan (2003). Bank Integration and State Business Cycles. National Bureau of Economic Research NBER. Working Paper 9704. Cambridge MA.

Nickell, S. (1997). Unemployment and Labor Market Rigidities: Europe versus North America. Journal of Economic Perspectives 11: 55-74.

Owyang, M.T., J. Piger, and H.J. Wall (2003). Business Cycle Phases in U.S. States. Federal Reserve Bank of St. Louis. Working Paper 2003-011E. St Louis.

Ramey, G. and V.A. Ramey (1995). Cross-country evidence on the link between volatility and growth. American Economic Review 85: 1138-1159.

Rodrik, D. (1997). Has Globalization Gone too Far? Institute for International Economics, Washington D.C. 51.

Scarpetta, S. (1996). Assessing the role of labour market policies and institutional settings on unemployment. OECD Economic Studies 26. Paris.

Schöb, R. and D.E. Wildasin (2007). Worker Mobility, Earnings Risk and Contract Structure. Regional Science and Urban Economics 37(2): 141-164.

Senay, O. (1998). The Effects of Goods and Financial Market Integration on Macroeconomic Volatility. The Manchester School Supplement 66: 39-61.

Simon, C.J., and C. Nardelli (1992). Does industrial diversity always reduce unemployment? Evidence from the great depression and after. Economic Inquiry 30(2): 384-97.

Stock, J.H., and M.W. Watson (2003). Has the Business Cycle Changed? National Bureau of Economic Research NBER. Working Paper 9127.

Uhlig, H., and M. O. Ravn (2001). On adjusting the HP-filter for the frequency of Observations. CESifo Working Paper 479. Munich. 


\section{Data Appendix}

Employment: We use data provided by a working committee of employment statistics (Erwerbstätigenrechnung des Bundes und der Länder). This dataset contains annual average values of the employees at the state level for the years 1970-2005. Freelancers are included.

Government revenues and expenditures: We use data from the German Federal Statistic Office (Statistisches Bundesamt) which contain information about the aggregated government revenues and expenditures at the state level. Data for the West German states are available since 1985, for the East German states since 1992.

Industry diversification: Herfindahl index computed for the number of workers in 15 industrial sectors. We calculate this index as:

$D I V_{i, t}=\sum_{j=1}^{n}\left(\frac{E R W_{i, j, t}}{E R W_{i, t}}\right)^{2}$, where $D I V_{i, t}$ is the industry diversification of state $i$ in year $t$, $E R W_{i, j, t}$ is the number of employees in state $i$, in sector $j$ in year $t, E R W_{i, t}$ is the number of employees in state $i$ in year $t, n$ is the total number of employees in state $i$ in year $t$. Sectoral employment data are obtained from a working committee of employment statistics (Arbeitskreis Erwerbstätigenrechnung des Bundes und der Länder) for the years 1991-2004.

Long-term unemployment rate: The data are taken from the German Working Agency (Bundesagentur für Arbeit). Long-term unemployed are persons who are unemployed more than one year. We use the data from 1977-2003.

Openness: State-level exports and imports relative to state GDP. The data are taken from the German Federal Statistic Office (Statistisches Bundesamt)

Output: Data we use are taken from the German Federal Statistic Office (Statistisches Bundesamt). We use the price-adjusted GDP growth at state level, for the West German States since 1971, for the East German states since 1991.

Service sector: We use sectoral data from from a working committee of employment statistics (Arbeitskreis Erwerbstätigenrechnung des Bundes und der Länder) for the years 1970-2004 to compute the share of employees in the service sector

Unionization: Data on the share of employees organized in German unions are taken from the German employees association (Deutscher Gewerkschaftsbund). 


\section{Graph 1: Employment Volatility by German State}

This Graph plots the volatility of regional employment growth for the West German states. Employment growth is the year-to-year cyclical change in the level of employment. The cyclical component is obtained using the Hodrick-Prescott-Filter. Volatility is the standard deviation of employment growth over a 5-year moving window. We show the unconditional volatility of employment growth and the conditional volatility of employment growth based on the residual of a regression of employment growth on time fixed effects and five lags of the dependent variable.

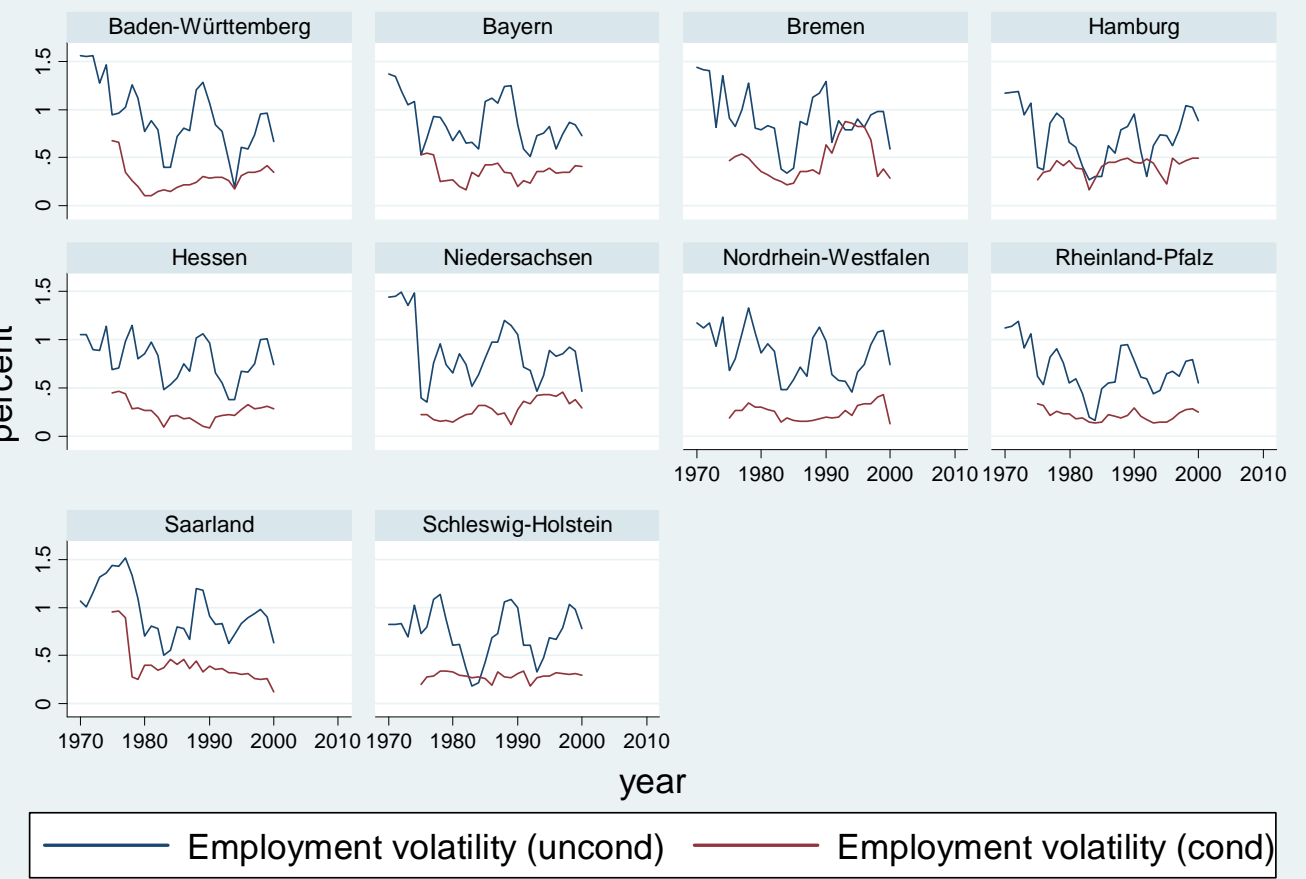

Graphs by bula

Source: German Statistical Office, authors’ calculations. 


\section{Graph 2: Trade Openness by German State}

Trade openness is the sum of state-level imports and exports over state-level GDP.

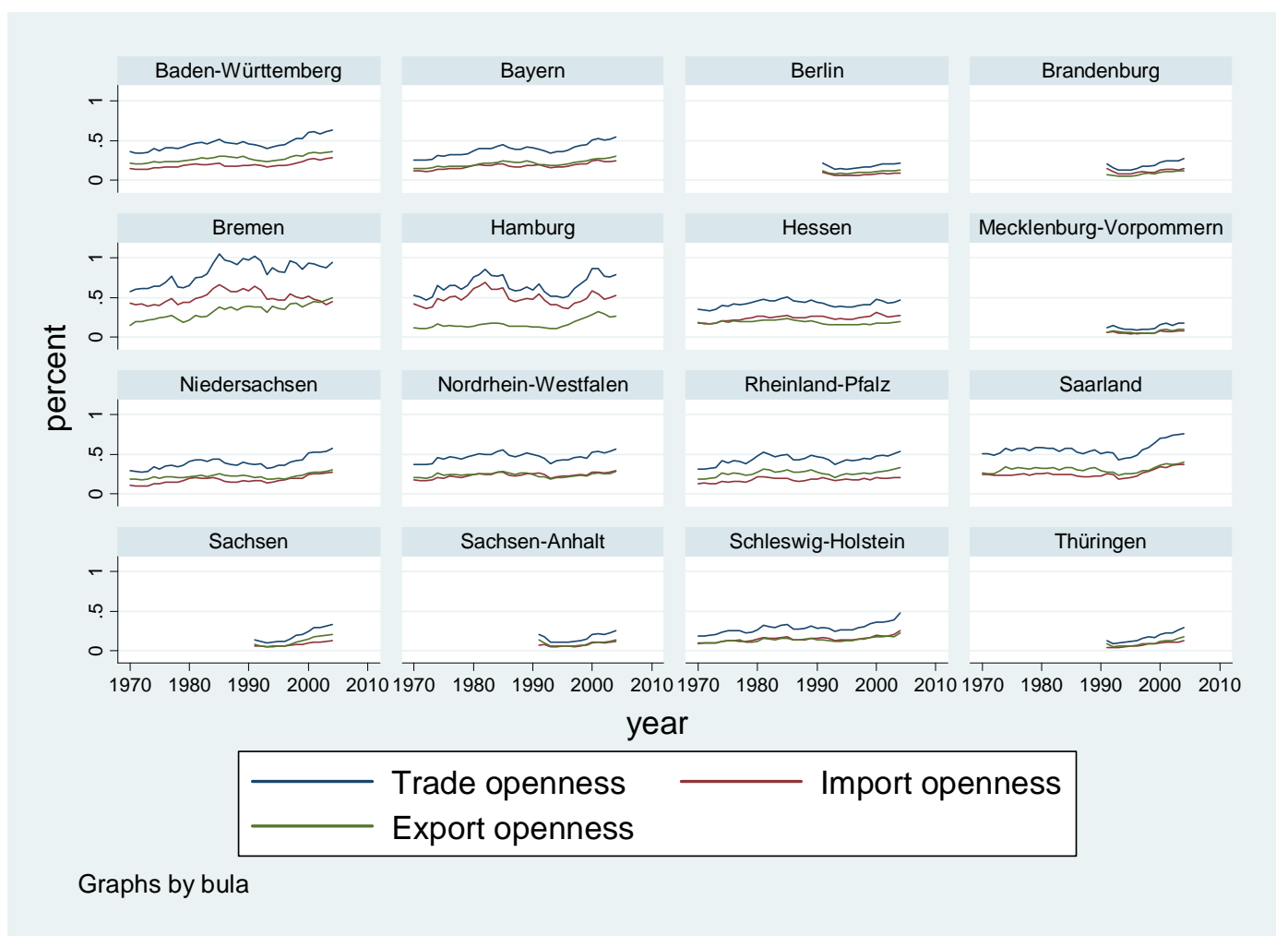

Source: German Statistical Office, authors’ calculations. 
Table 1: Descriptive Statistics

See the Data Appendix for a detailed description of these variables. 'Volatility' is the standard deviation of the growth rate of the respective variables over a fiveyear rolling window.

\begin{tabular}{|c|c|c|c|c|c|}
\hline Variable & Observations & Mean & Std. Dev. & Min & Max \\
\hline Degree of industrial diversification & 240 & 0.113 & 0.013 & 0.094 & 0.170 \\
\hline Export openness (\%) & 455 & 0.200 & 0.088 & 0.040 & 0.500 \\
\hline Import openness (\%) & 454 & 0.216 & 0.138 & 0.040 & 0.690 \\
\hline Long-term unemployment rate (\%) & 330 & 0.289 & 0.073 & 0.129 & 0.377 \\
\hline Service sector (\%) & 450 & 0.631 & 0.096 & 0.378 & 0.855 \\
\hline Trade openness (\%) & 434 & 0.427 & 0.199 & 0.083 & 1.049 \\
\hline Unionization (\%) & 450 & 0.282 & 0.044 & 0.198 & 0.336 \\
\hline Volatility of employment growth (\%, conditional) & 290 & 0.345 & 0.169 & 0.081 & 0.969 \\
\hline Volatility of employment growth (\%, unconditional) & 370 & 0.925 & 0.497 & 0.160 & 4.176 \\
\hline Volatility of nominal government expenditures (\%) & 214 & 2.914 & 1.440 & 0.302 & 6.389 \\
\hline Volatility of nominal government revenues (\%) & 214 & 3.883 & 2.358 & 0.517 & 12.611 \\
\hline Volatility of real output growth (\%) & 370 & 1.568 & 0.646 & 0.120 & 3.420 \\
\hline
\end{tabular}




\section{Table 2: Determinants of Regional Employment Volatility}

This Table presents results of fixed effects panel estimators. $t$-values based on robust standard errors clustered at the state-level are reported in brackets. The full sample includes information for 16 German states, the West German sample includes information for 10 West German states (excluding Berlin). Data are for the years 1971-2005. The dependent variable is the volatility of employment, calculated as the squared growth rate of employment. 'Unconditional' is the unadjusted employment growth, 'conditional' are the squared residuals of a regression of the growth rate of employment on up to five own lags, year fixed effects, and a unification dummy. The conditional and unconditional volatility of output growth and government spending and revenue are computed analogously. See the Data Appendix for details on the specifications of the variables. ${ }^{* * *}, * *, *=$ significant at the $1 \%, 5 \%, 10 \%$ level.

a) Full sample

\begin{tabular}{|c|c|c|c|c|c|c|c|c|c|c|}
\hline & \multicolumn{7}{|c|}{ Unconditional employment volatility } & \multicolumn{3}{|c|}{ Conditional employment volatility } \\
\hline & $(1)$ & $(2)$ & (3) & (4) & $(5)$ & (6) & $(7)$ & $(8)$ & (9) & $(10)$ \\
\hline Volatility of output growth & $\begin{array}{c}0.205^{* *} \\
(2.70)\end{array}$ & $\begin{array}{c}0.206^{* *} \\
(2.75)\end{array}$ & $\begin{array}{c}0.209 * * \\
(2.78)\end{array}$ & $\begin{array}{c}0.240 * * \\
(2.80)\end{array}$ & $\begin{array}{c}0.370 * * * \\
(2.95)\end{array}$ & $\begin{array}{c}0.199 * * \\
(2.92)\end{array}$ & $\begin{array}{c}0.168^{* *} \\
(2.94)\end{array}$ & $\begin{array}{c}0.056^{* * *} \\
(3.43)\end{array}$ & $\begin{array}{c}0.057 * * * \\
(3.33)\end{array}$ & $\begin{array}{c}0.058 * * * \\
(3.88)\end{array}$ \\
\hline Trade openness & $\begin{array}{l}0.486 \\
(0.13)\end{array}$ & & & $\begin{array}{l}3.150 \\
(0.74)\end{array}$ & $\begin{array}{l}3.477 \\
(0.33)\end{array}$ & $\begin{array}{l}-2.173 \\
(0.68)\end{array}$ & $\begin{array}{l}-0.159 \\
(0.10)\end{array}$ & $\begin{array}{l}0.276 \\
(1.13)\end{array}$ & & \\
\hline Import openness & & $\begin{array}{l}-1.726 \\
(0.47)\end{array}$ & & & & & & & $\begin{array}{l}-0.167 \\
(1.38)\end{array}$ & \\
\hline Export openness & & & $\begin{array}{l}4.525 \\
(0.71)\end{array}$ & & & & & & & $\begin{array}{l}1.047^{*} \\
(1.83)\end{array}$ \\
\hline Volatility of government revenue & & & & $\begin{array}{l}-0.006 \\
(1.12)\end{array}$ & & & & & & \\
\hline Volatility of government spending & & & & $\begin{array}{l}0.005 \\
(0.62)\end{array}$ & & & & & & \\
\hline Industry diversification & & & & & $\begin{array}{c}-171.245 \\
(1.44)\end{array}$ & & & & & \\
\hline Unemployment & & & & & & $\begin{array}{c}-23.789 \\
(1.55)\end{array}$ & & & & \\
\hline Service sector & & & & & & $\begin{array}{c}-32.501^{* * *} \\
(3.12)\end{array}$ & & & & \\
\hline Long-term unemployment rate & & & & & & & $\begin{array}{l}0.331 \\
(0.20) \\
\end{array}$ & & & \\
\hline
\end{tabular}

Table 2a continues ... 
Table 2a continued ...

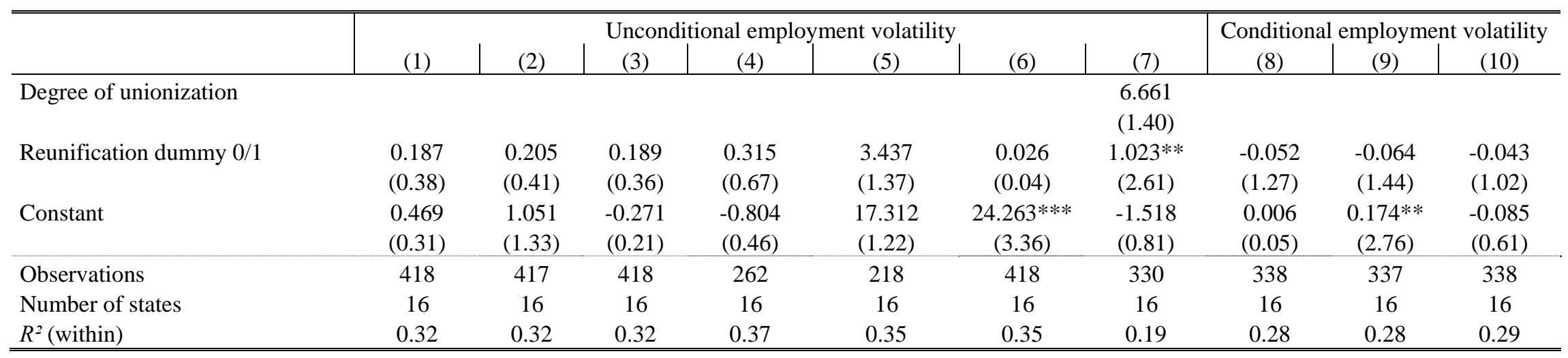


b) West Germany

\begin{tabular}{|c|c|c|c|c|c|c|c|c|c|c|}
\hline & \multicolumn{7}{|c|}{ Unconditional employment volatility } & \multicolumn{3}{|c|}{ Conditional employment volatility } \\
\hline & $(1)$ & $(2)$ & (3) & $(4)$ & $(5)$ & $(6)$ & $(7)$ & (8) & (9) & $(10)$ \\
\hline Volatility of output growth & $\begin{array}{c}0.029 * * * \\
(4.22)\end{array}$ & $\begin{array}{c}0.030 * * * \\
(4.06)\end{array}$ & $\begin{array}{c}0.029 * * * \\
(3.91)\end{array}$ & $\begin{array}{l}0.023 \\
(1.33)\end{array}$ & $\begin{array}{c}0.056^{* * *} \\
(4.39)\end{array}$ & $\begin{array}{c}0.030^{* * *} \\
(4.00)\end{array}$ & $\begin{array}{c}0.075^{* * *} \\
(5.49)\end{array}$ & $\begin{array}{l}0.024 \\
(1.69)\end{array}$ & $\begin{array}{l}0.024 \\
(1.53)\end{array}$ & $\begin{array}{l}0.027 * \\
(2.08)\end{array}$ \\
\hline Trade openness & $\begin{array}{c}-0.293 \\
(0.65)\end{array}$ & & & $\begin{array}{l}0.261 \\
(0.29)\end{array}$ & $\begin{array}{l}1.270 \\
(0.96)\end{array}$ & $\begin{array}{c}-0.390 \\
(0.61)\end{array}$ & $\begin{array}{c}0.786 * * \\
(2.42)\end{array}$ & $\begin{array}{c}0.332 * \\
(1.84)\end{array}$ & & \\
\hline Import openness & & $\begin{array}{l}-0.708 \\
(1.01)\end{array}$ & & & & & & & $\begin{array}{l}-0.029 \\
(0.46)\end{array}$ & \\
\hline Export openness & & & $\begin{array}{l}0.235 \\
(0.24)\end{array}$ & & & & & & & $\begin{array}{c}0.983^{*} \\
(1.97)\end{array}$ \\
\hline Volatility of government revenue & & & & $\begin{array}{l}-0.000 \\
(0.09)\end{array}$ & & & & & & \\
\hline Volatility of government spending & & & & $\begin{array}{c}0.008 * \\
(1.87)\end{array}$ & & & & & & \\
\hline Industry diversification & & & & & $\begin{array}{c}-10.950 \\
(1.05)\end{array}$ & & & & & \\
\hline Unemployment & & & & & & $\begin{array}{l}-1.757 \\
(0.68)\end{array}$ & & & & \\
\hline Service sector & & & & & & $\begin{array}{l}-1.987 \\
(0.71)\end{array}$ & & & & \\
\hline Long-term unemployment rate & & & & & & & $\begin{array}{c}-2.831^{* * *} \\
(3.95)\end{array}$ & & & \\
\hline Degree of unionization & & & & & & & $\begin{array}{c}-3.273^{* * *} \\
(4.24)\end{array}$ & & & \\
\hline Reunification dummy 0/1 & $\begin{array}{c}-1.566^{* *} \\
(2.29)\end{array}$ & $\begin{array}{c}-1.560 * * \\
(2.29)\end{array}$ & $\begin{array}{c}-1.561^{*} \\
(2.26)\end{array}$ & $\begin{array}{c}1.405^{* * * *} \\
(5.03)\end{array}$ & $\begin{array}{c}-0.900 * * \\
(2.78)\end{array}$ & $\begin{array}{c}-1.255 \\
(1.57)\end{array}$ & $\begin{array}{c}0.289 * * * \\
(5.46)\end{array}$ & $\begin{array}{l}-0.050 \\
(1.22)\end{array}$ & $\begin{array}{c}-0.028 \\
(0.95)\end{array}$ & $\begin{array}{l}-0.043 \\
(1.00)\end{array}$ \\
\hline Constant & $\begin{array}{c}3.327 * * * \\
(4.33)\end{array}$ & $\begin{array}{c}3.347 * * * \\
(5.02)\end{array}$ & $\begin{array}{c}3.152 * * * \\
(3.95)\end{array}$ & $\begin{array}{r}0.172 \\
(0.43) \\
\end{array}$ & $\begin{array}{c}1.904^{*} \\
(2.06)\end{array}$ & $\begin{array}{c}4.498 * * \\
(2.54)\end{array}$ & $\begin{array}{c}1.745^{* * * *} \\
(5.24)\end{array}$ & $\begin{array}{c}-0.061 \\
(0.51)\end{array}$ & $\begin{array}{c}0.084 * * \\
(2.40)\end{array}$ & $\begin{array}{r}-0.119 \\
(0.87)\end{array}$ \\
\hline Observations & 340 & 339 & 340 & 190 & 140 & 340 & 270 & 290 & 289 & 290 \\
\hline Number of states & 10 & 10 & 10 & 10 & 10 & 10 & 10 & 10 & 10 & 10 \\
\hline$R^{2}$ (within) & 0.62 & 0.62 & 0.62 & 0.68 & 0.74 & 0.62 & 0.20 & 0.19 & 0.19 & 0.20 \\
\hline
\end{tabular}




\section{Table 3: Determinants of Regional Employment Volatility (Quasi Panel)}

This Table presents results of fixed effects panel estimators. $t$-values based on robust standard errors clustered at the state-level are reported in brackets. All regressions are for all German states. Data are for the years 1975-2005. The dependent variable is the volatility of employment, calculated as the standard deviation of a non-overlapping 5-year window. 'Unconditional' is the unadjusted volatility of employment growth, 'conditional' is the volatility of the residuals of a regression of the growth rate of employment on up to five own lags, year fixed effects, and a unification dummy. See the Data Appendix for details on the specifications of the variables. $* * *, * *, *=$ significant at the $1 \%, 5 \%, 10 \%$ level.

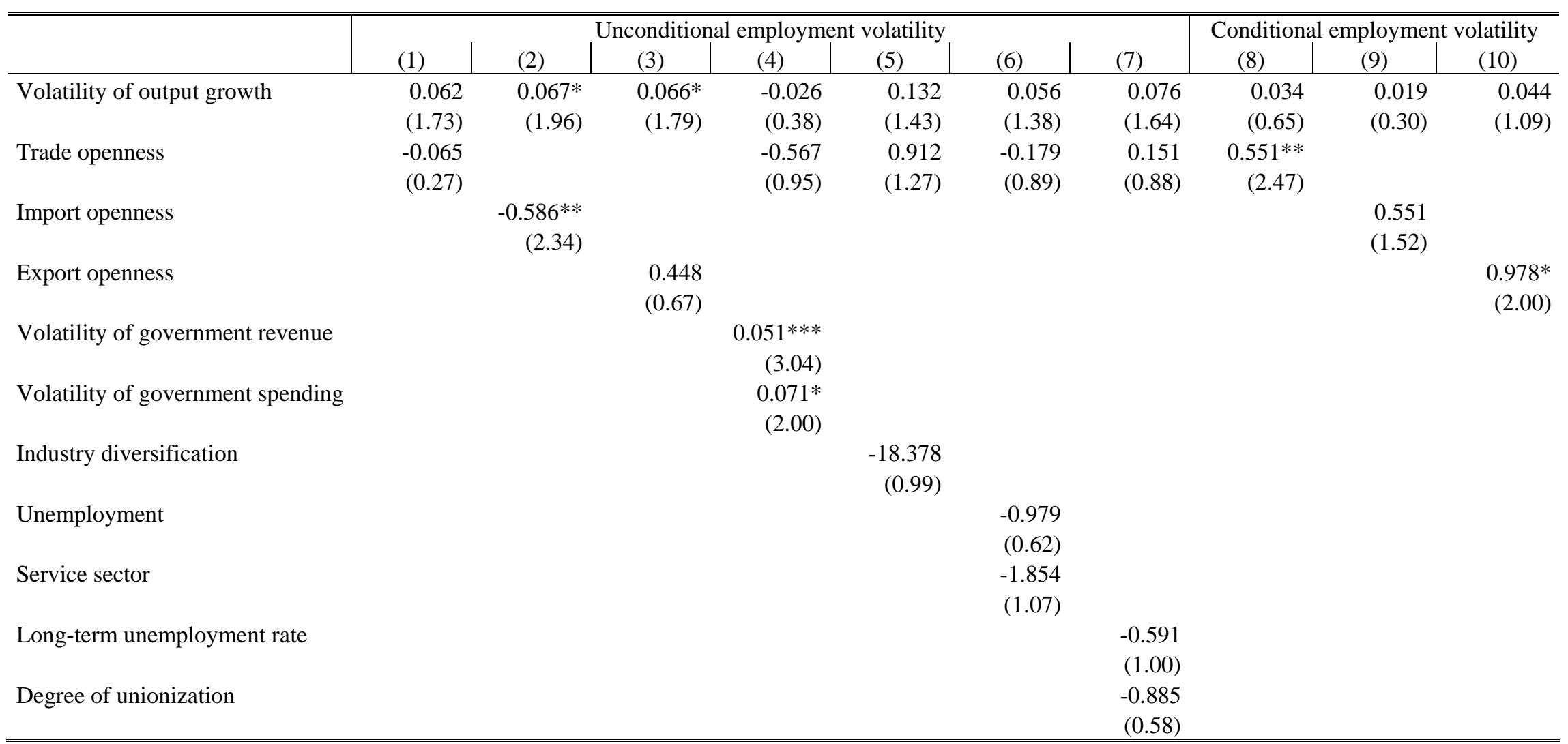

Table 3 continues ... 
Table 3 continued

\begin{tabular}{|c|c|c|c|c|c|c|c|c|c|c|}
\hline & \multicolumn{7}{|c|}{ Dependent variable: unconditional employment volatility } & \multicolumn{3}{|c|}{$\begin{array}{l}\text { Dependent variable: conditional } \\
\text { employment volatility }\end{array}$} \\
\hline & $(1)$ & (2) & (3) & (4) & (5) & (6) & $(7)$ & $(8)$ & $(9)$ & $(10)$ \\
\hline Reunification dummy 0/1 & $\begin{array}{r}0.054 \\
(0.47)\end{array}$ & $\begin{array}{r}0.066 \\
(0.58)\end{array}$ & $\begin{array}{r}0.046 \\
(0.42)\end{array}$ & $\begin{array}{r}-0.174^{*} \\
(1.77)\end{array}$ & $\begin{array}{r}0.276 \\
(1.55)\end{array}$ & $\begin{array}{r}0.338 \\
(1.33)\end{array}$ & $\begin{array}{r}0.205^{* * *} \\
(3.08)\end{array}$ & $\begin{array}{r}0.145^{* *} \\
(2.21)\end{array}$ & $\begin{array}{r}0.107^{*} \\
(2.02)\end{array}$ & $\begin{array}{r}0.126 \\
(1.43)\end{array}$ \\
\hline Constant & $\begin{array}{r}0.700^{* * *} \\
(7.41)\end{array}$ & $\begin{array}{r}0.778^{* * *} \\
(10.46)\end{array}$ & $\begin{array}{r}0.590^{* * * *} \\
(4.40)\end{array}$ & $\begin{array}{r}0.718^{* *} \\
(2.40)\end{array}$ & $\begin{array}{l}2.196 \\
(1.20)\end{array}$ & $\begin{array}{r}1.798^{*} \\
(1.88)\end{array}$ & $\begin{array}{r}0.939 * \\
(1.80)\end{array}$ & $\begin{array}{r}-0.03 \\
(0.19)\end{array}$ & $\begin{array}{l}0.127 \\
(0.99)\end{array}$ & $\begin{array}{l}0.015 \\
(0.09)\end{array}$ \\
\hline Observations & 82 & 82 & 82 & 52 & 32 & 82 & 62 & 66 & 66 & 66 \\
\hline Number of states & 16 & 16 & 16 & 16 & 16 & 16 & 16 & 16 & 16 & 16 \\
\hline$R^{2}$ & 0.57 & 0.57 & 0.57 & 0.6 & 0.41 & 0.58 & 0.37 & 0.19 & 0.17 & 0.18 \\
\hline
\end{tabular}




\section{Table 4: Determinants of Regional Employment Volatility (Robustness Check without City States)}

This Table presents results of fixed effects panel estimators. $t$-values based on robust standard errors clustered at the state-level are reported in brackets. Data are for the years 1975-2005. The dependent variable is the volatility of employment computed as the squared residual of a regression of the growth rate of employment on up to five own lags, year fixed effects, and a unification dummy. See the Data Appendix for details on the specifications of the variables. ***, **, $*=$ significant at the $1 \%, 5 \%, 10 \%$ level.

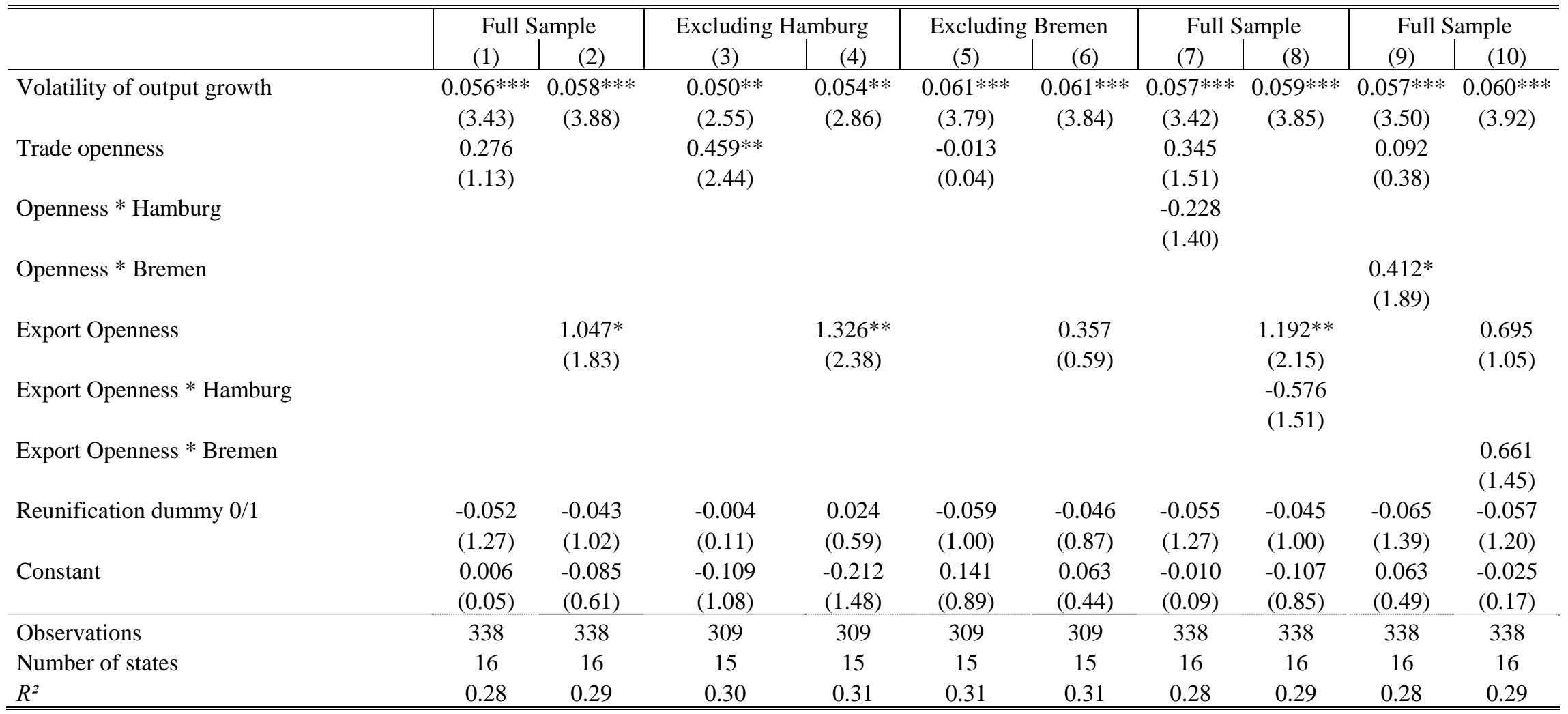


Table 5: Determinants of Regional Employment Volatility (Heteroscedastic Regression Model)

This Table presents results of a heteroscedastic regression model as proposed by Harvey (1967). Observations are clustered at the state level. Robust $t$-values are reported in brackets. Regressions for the full sample include a full set of time and state-fixed effects. Regressions for the West German sample include time fixed effects only since the model did not converge for all specifications using state fixed effects. Data are for the years 1970-2003. See the Data Appendix for details on the specifications of the variables. ${ }^{* * *},{ }^{* *}, *=$ significant at the $1 \%, 5 \%, 10 \%$ level.

\begin{tabular}{|c|c|c|c|c|c|c|c|c|}
\hline & \multicolumn{4}{|c|}{ Full sample } & \multicolumn{4}{|c|}{ West Germany } \\
\hline & $(1)$ & (2) & (3) & (4) & (5) & (6) & (7) & (8) \\
\hline \multicolumn{9}{|l|}{ Mean equation } \\
\hline Output growth & $\begin{array}{r}0.177^{* *} \\
(2.30)\end{array}$ & $\begin{array}{r}0.185^{* * *} \\
(0.53)\end{array}$ & $\begin{array}{r}0.190 * * * \\
(0.59)\end{array}$ & $\begin{array}{r}0.187^{* * *} \\
(0.40)\end{array}$ & $\begin{array}{r}0.182 * * * \\
(6.04)\end{array}$ & $\begin{array}{r}0.182 * * * \\
(5.62)\end{array}$ & $\begin{array}{r}0.208^{* * *} \\
(0.20)\end{array}$ & $\begin{array}{r}0.154^{* * *} \\
(0.69)\end{array}$ \\
\hline Wage growth & $\begin{array}{r}-0.272 * \\
(1.65)\end{array}$ & $\begin{array}{r}-0.265^{* *} \\
(1.96)\end{array}$ & $\begin{array}{r}-0.268 * * \\
(2.68)\end{array}$ & $\begin{array}{r}-0.272 * * * \\
(2.57)\end{array}$ & $\begin{array}{r}-0.186 * * * \\
(2.61)\end{array}$ & $\begin{array}{r}-0.185^{* *} \\
(0.46)\end{array}$ & $\begin{array}{r}-0.197 * * * \\
(0.03)\end{array}$ & $\begin{array}{r}-0.298 * * * \\
(3.41)\end{array}$ \\
\hline Trade openness & $\begin{array}{r}-1.063 \\
(0.68)\end{array}$ & & & $\begin{array}{r}0.537 \\
(0.34)\end{array}$ & $\begin{array}{r}-0.639 * * * \\
(1.94)\end{array}$ & & & $\begin{array}{r}-0.250 \\
(0.80)\end{array}$ \\
\hline Import openness & & $\begin{array}{r}0.511 \\
(1.03)\end{array}$ & & & & $\begin{array}{r}-0.760^{* * * *} \\
(5.05)\end{array}$ & & \\
\hline Export openness & & & $\begin{array}{r}-1.629 \\
(0.58)\end{array}$ & & & & $\begin{array}{r}-0.988 * * \\
(2.38)\end{array}$ & \\
\hline Unemployment & & & & $\begin{array}{r}-10.568^{* *} \\
(0.36)\end{array}$ & & & & $\begin{array}{r}-6.779 * * * \\
(4.07)\end{array}$ \\
\hline Service sector & & & & $\begin{array}{r}5.365 \\
(0.39)\end{array}$ & & & & $\begin{array}{r}0.174 \\
(0.57)\end{array}$ \\
\hline
\end{tabular}

Table 5 continues ... 
Table 5 continued

\begin{tabular}{|c|c|c|c|c|c|c|c|c|}
\hline & \multicolumn{4}{|c|}{ Full sample } & \multicolumn{4}{|c|}{ West Germany } \\
\hline & (1) & (2) & $(3)$ & (4) & (5) & (6) & (7) & (8) \\
\hline \multicolumn{9}{|c|}{ Variance equation } \\
\hline Output growth & $\begin{array}{r}0.052 \\
(4.08)\end{array}$ & $\begin{array}{r}0.063 \\
(0.55)\end{array}$ & $\begin{array}{r}0.067 \\
(4.06)\end{array}$ & $\begin{array}{r}0.037 \\
(4.10)\end{array}$ & $\begin{array}{r}0.048 \\
(0.35)\end{array}$ & $\begin{array}{r}0.023 \\
(0.15)\end{array}$ & $\begin{array}{c}-0.022 \\
(7.80)\end{array}$ & $\begin{array}{r}0.065 \\
(3.76)\end{array}$ \\
\hline Wage growth & $\begin{array}{r}0.153^{* *} \\
(2.00)\end{array}$ & $\begin{array}{r}0.136^{*} \\
(2.00)\end{array}$ & $\begin{array}{r}0.136^{* *} \\
(1.83)\end{array}$ & $\begin{array}{r}0.156 * * * \\
(2.61)\end{array}$ & $\begin{array}{r}-0.142 \\
(0.48)\end{array}$ & $\begin{array}{l}-0.113 \\
(2.54)\end{array}$ & $\begin{array}{l}-0.008 \\
(2.89)\end{array}$ & $\begin{array}{r}-0.274 \\
(0.83)\end{array}$ \\
\hline Trade openness & $\begin{array}{r}29.428 \\
(0.11)\end{array}$ & & & $\begin{array}{r}-0.617 \\
(0.25)\end{array}$ & $\begin{array}{r}1.684 * * \\
(6.32)\end{array}$ & & & \\
\hline Import openness & & $\begin{array}{r}-3.149 \\
(0.44)\end{array}$ & & & & $\begin{array}{r}1.965 * \\
(1.69)\end{array}$ & & \\
\hline Export openness & & & $\begin{array}{c}-1.947 \\
(0.59)\end{array}$ & & & & $\begin{array}{r}2.098 \\
(0.97)\end{array}$ & \\
\hline Unemployment & & & & $\begin{array}{r}5.447 \\
(2.50)\end{array}$ & & & & $\begin{array}{r}6.279 \\
(0.48)\end{array}$ \\
\hline Service sector & & & & $\begin{array}{l}4.187 \\
(0.86)\end{array}$ & & & & $\begin{array}{l}1.681 \\
(0.40)\end{array}$ \\
\hline Observations & 418 & 417 & 418 & 418 & 340 & 339 & 340 & 340 \\
\hline
\end{tabular}




\section{CESifo Working Paper Series}

for full list see www.cesifo-group.org/wp

(address: Poschingerstr. 5, 81679 Munich, Germany, office@cesifo.de)

2233 Stefan Bach, Giacomo Corneo and Viktor Steiner, Effective Taxation of Top Incomes in Germany, 1992-2002, February 2008

2234 Robert S. Chirinko, $\sigma:$ The Long And Short Of It, February 2008

2235 Volker Grossmann and Holger Strulik, Should Continued Family Firms Face Lower Taxes than other Estates?, February 2008

2236 Guido Tabellini, The Scope of Cooperation: Values and Incentives, February 2008

2237 Heinrich W. Ursprung and Christian Wiermann, Reputation, Price, and Death: An Empirical Analysis of Art Price Formation, March 2008

2238 Hans Fehr and Christian Habermann, Private Retirement Savings in Germany: The Structure of Tax Incentives and Annuitization, March 2008

2239 Joseph Francois and Ian Wooton, Market Structure and Market Access, March 2008

2240 Hiroyuki Kasahara and Beverly Lapham, Productivity and the Decision to Import and Export: Theory and Evidence, March 2008

2241 Gary E. Bolton and Axel Ockenfels, Does Laboratory Trading Mirror Behavior in Real World Markets? Fair Bargaining and Competitive Bidding on EBay, March 2008

2242 Atsushi Oshima, B. Ravikumar and Raymond Riezman, Entrepreneurship, Organization Capital and the Evolution of the Firm, March 2008

2243 Walter Krämer and Sebastian Schich, Large-Scale Disasters and the Insurance Industry, March 2008

2244 Leif Danziger, Adjustment Costs, Inventories and Output, March 2008

2245 Anne van Aaken, Lars P. Feld and Stefan Voigt, Power over Prosecutors Corrupts Politicians: Cross Country Evidence Using a New Indicator, March 2008

2246 Hans-Christian Heinemeyer, Max-Stephan Schulze and Nikolaus Wolf, Endogenous Borders? The Effects of New Borders on Trade in Central Europe 1885-1933, March 2008

2247 Johannes Becker and Clemens Fuest, Tax Competition - Greenfield Investment versus Mergers and Acquisitions, March 2008

2248 Giorgio Bellettini and Hubert Kempf, Why not in your Backyard? On the Location and Size of a Public Facility, March 2008 
2249 Jose Luis Evia, Roberto Laserna and Stergios Skaperdas, Socio-Political Conflict and Economic Performance in Bolivia, March 2008

2250 Bas Jacobs and A. Lans Bovenberg, Optimal Taxation of Human Capital and the Earnings Function, March 2008

2251 Jan-Egbert Sturm and Timo Wollmershäuser, The Stress of Having a Single Monetary Policy in Europe, March 2008

2252 Guido Schwerdt, Labor Turnover before Plant Closure: 'Leaving the Sinking Ship' vs. 'Captain Throwing Ballast Overboard', March 2008

2253 Keith E. Maskus and Shuichiro Nishioka, Development-Related Biases in Factor Productivities and the HOV Model of Trade, March 2008

2254 Jeremy Edwards and Sheilagh Ogilvie, Contract Enforcement, Institutions and Social Capital: the Maghribi Traders Reappraised, March 2008

2255 Imed Drine and Christophe Rault, Purchasing Power Parity for Developing and Developed Countries. What can we Learn from Non-Stationary Panel Data Models?, March 2008

2256 Scott Alan Carson, Health, Wealth and Inequality: a Contribution to the Debate about the Relationship between Inequality and Health, March 2008

2257 C.A.E. Goodhart, The Regulatory Response to the Financial Crisis, March 2008

2258 Stefan Bauernschuster, Oliver Falck and Stephan Heblich, The Impact of Continuous Training on a Firm's Innovations, March 2008

2259 Michael Grimm and Stephan Klasen, Geography vs. Institutions at the Village Level, March 2008

2260 Fwu-Ranq Chang, Property Insurance, Portfolio Selection and their Interdependence, March 2008

2261 J. Atsu Amegashie and Marco Runkel, The Paradoxes of Revenge in Conflicts, March 2008

2262 Hans Jarle Kind, Marko Koethenbuerger and Guttorm Schjelderup, Efficiency Enhancing Taxation in Two-sided Markets, March 2008

2263 M. Hashem Pesaran, Til Schuermann and L. Vanessa Smith, Forecasting Economic and Financial Variables with Global VARs, March 2008

2264 Volker Grossmann, Entrepreneurial Innovation and Sustained Long-run Growth without Weak or Strong Scale Effects, March 2008

2265 Robert S. Chirinko and Huntley Schaller, The Irreversibility Premium, March 2008 
2266 Andrea Galeotti and José Luis Moraga-González, Platform Intermediation in a Market for Differentiated Products, April 2008

2267 Torben M. Andersen and Michael Svarer, The Role of Workfare in Striking a Balance between Incentives and Insurance in the Labour Market, April 2008

2268 Harald Badinger, Cyclical Fiscal Policy, Output Volatility, and Economic Growth, April 2008

2269 Thomas Aronsson and Erkki Koskela, Outsourcing and Optimal Nonlinear Taxation: A Note, April 2008

2270 Gary E. Bolton, Claudia Loebbecke and Axel Ockenfels, How Social Reputation Networks Interact with Competition in Anonymous Online Trading: An Experimental Study, April 2008

2271 Nikolaus Wolf, Scylla and Charybdis. Explaining Europe's Exit from Gold, January 1928 - December 1936, April 2008

2272 Michael Funke and Marc Gronwald, The Undisclosed Renminbi Basket: Are the Markets Telling us something about where the Renminbi - US Dollar Exchange Rate is Going?, April 2008

2273 Thor Olav Thoresen and Annette Alstadsæter, Shifts in Organizational Form under a Dual Income Tax System, April 2008

2274 Helge Berger and Volker Nitsch, Too many Cooks? Committees in Monetary Policy, April 2008

2275 Yin-Wong Cheung and Eiji Fujii, Deviations from the Law of One Price in Japan, April 2008

2276 Michael S. Michael, Sajal Lahiri and Panos Hatzipanayotou, Integrated Reforms of Indirect Taxes in the Presence of Pollution, April 2008

2277 Bas Jacobs, Is Prescott Right? Welfare State Policies and the Incentives to Work, Learn and Retire, April 2008

2278 Burkhard Heer and Alfred Maußner, Value Function Iteration as a Solution Method for the Ramsey Model, April 2008

2279 Jarko Fidrmuc and Christa Hainz, Integrating with their Feet: Cross-Border Lending at the German-Austrian Border, April 2008

2280 Kristof Dascher and Alexander Haupt, The Political Economy of Regional Integration Projects at Borders where Rich and Poor Meet: The Role of Cross-Border Shopping and Community Sorting, April 2008

2281 Katrin Assenmacher-Wesche and M. Hashem Pesaran, A VECX* Model of the Swiss Economy, April 2008 
2282 Christophe Rault, Robert Sova and Ana Maria Sova, Modeling International Trade Flows between CEEC and OECD Countries, April 2008

2283 Timo Boppart, Josef Falkinger, Volker Grossmann, Ulrich Woitek and Gabriela Wüthrich, Qualifying Religion: The Role of Plural Identities for Educational Production, April 2008

2284 Armin Falk, David Huffman and W. Bentley MacLeod, Institutions and Contract Enforcement, April 2008

2285 Axel Dreher and Stefan Voigt, Does Membership in International Organizations Increase Governments' Credibility? Testing the Effects of Delegating Powers, April 2008

2286 Xavier Freixas and Bruno M. Parigi, Lender of Last Resort and Bank Closure Policy, April 2008

2287 Regina Dionisius, Samuel Muehlemann, Harald Pfeifer, Günter Walden, Felix Wenzelmann and Stefan C. Wolter, Cost and Benefit of Apprenticeship Training - A Comparison of Germany and Switzerland, April 2008

2288 Francesco Daveri and Cecilia Jona-Lasinio, Off-Shoring and Productivity Growth in the Italian Manufacturing Industries, April 2008

2289 Mikael Priks, Do Surveillance Cameras Affect Unruly Behavior? A Close Look at Grandstands, April 2008

2290 Marianna Belloc and Daniela Federici, A Two-Country NATREX Model for the Euro/Dollar, April 2008

2291 Nicolas Treich, The Value of a Statistical Life under Ambiguity Aversion, April 2008

2292 J. Atsu Amegashie, Socially-Tolerable Discrimination, April 2008

2293 M. Hashem Pesaran and Andreas Pick, Forecasting Random Walks Under Drift Instability, April 2008

2294 Steven Brakman, Gus Garita, Harry Garretsen and Charles van Marrewijk, Unlocking the Value of Cross-Border Mergers and Acquisitions, May 2008

2295 Eric O’N. Fisher and Kathryn G. Marshall, The Structure of the American Economy, May 2008

2296 Claudia M. Buch and Martin Schlotter, Regional Origins of Employment Volatility: Evidence from German States, May 2008 